\title{
South Estonian Literature: A New Phenomenon with a Centuries-long History
}

\author{
MART VELSKER
}

\begin{abstract}
The focus of the article is on South Estonian literature, with an aim to provide a survey of the phenomenon while discussing problems that arise in describing it. These problems are related to the small size of the literary corpus, transformation of modes of description through history, and variations in concepts. Irrespective of the problems, it seems useful to treat South Estonian literature as a separate set of texts; taking the use of South Estonian language as the defining characteristic appears to be the most productive approach. The administrative and linguistic history of South Estonia is different from that of North Estonia and has influenced the development of regional identities. Starting from the $17^{\text {th }}$ century, texts in South Estonian would be published mostly in the form of religious literature, and a South Estonian literary language based on the Tartu dialect was formed. The tradition based on religious literature disappeared at the beginning of the $20^{\text {th }}$ century, while other, and more explicitly literary, opportunities to employ South Estonian language arose. A new wave of South Estonian poetry introduced the second period of South Estonian literature in 1917, during which it was mostly considered as a dialectal branch of Estonian literature. 1987 marked the beginning of a third period that has been characterised by the emergence of literature written in the Vorru dialect and the spread of the Võru cultural movement. This most recent stage has brought about changes in the interpretative framework within which South Estonian literature is being discussed.
\end{abstract}

Keywords: South Estonian literature, Estonian literature, Tartu literature, Võru literature, Setu literature, Mulgi literature, minority discourse, literary history, literary dialect, cultural geography, national literatures, small literatures, vernacular literature

\section{Introduction}

Estonian literature is small, yet there are studies that regard the South Estonian literature as a separate phenomenon. These studies consider, on one hand, regional specificities (Northern and Southern Estonia have both geographical and historical differences), but even more frequently they focus on a region populated by speakers of South Estonian dialects and literature written there in local

DOI: http://dx.doi.org/10.12697/IL.2015.20.1.9 
languages. This linguistic region includes Estonia's second largest city Tartu, but also the town of Vorru. The Vorru dialect spoken in its surroundings has the most distinctive characteristics among the Estonian dialects today. Võru is situated in South-Eastern Estonia and the language-oriented approach considers both the southern and south-eastern regions of the country as South Estonia, while the south-western part often remains neglected.

While the author of this article is convinced that critical discussion of the topic is justified, there still seems to be no overwhelming consensus regarding the issue. One of the first questions to arise logically is: can such a small corpus contain an even smaller one that would still have a collective literary historical dimension and distinctive charateristics? It is also conspicuous that the understanding of South Estonian literature as a separate phenomenon with a specific tradition of its own has become widespread particularly during the past couple of decades. Why have no discussions of South Estonian literature emerged earlier? Did earlier history even contain the object of discussion, or has it been constructed by later interpretations? In addition to the size of the corpus and the history of interpretation, the scope of the meaning of the concept can also be seen as problematic. Often "South Estonian" literature is mentioned, yet the scope of the meaning of the concept has not been uniform in all cases. There are at least as many discussions that have "Võru literature" as their topic. Can terminological inconsistency be indicative of an inconsistency, or even nonexistence, of the object itself?

The present article attempts to clarify the terminological scope of the phrase "South Estonian literature", as well as provide possible insights into this literary tradition. The questions posed above will be touched upon in the course of the discussion. The question about the smallness of South Estonian literature might be answered first, yet not exhaustively, for it is possible to resume theoretical discussions of how small or great a literature "in general" can be. The existence of relatively small literary corpora, however, cannot be denied. For instance, Luxembourgian literary scholars have been holding debates over the issue whether there is a single Luxembourgian national literature or whether there are three due to linguistic reasons (Glesener 2012: 77). The size of the reading public should be approximately the same in case of Luxembourg and South Estonia, with the former appearing slightly bigger or smaller than the latter, depending on how many literatures Luxembourg is deemed to have. There are literary traditions in which the number of those participating in literary communication is certainly smaller than in the South Estonian case, irrespective of whether we take the population numbers in South Estonian counties (see Rahvaarv) or the number of South Estonian speakers as our point of reference. In the $21^{\text {st }}$ century the Võru dialect has proven to be the most vital one among the regional 
dialectals and has become the basis for the Võru literary language. The number of the speakers of the Vorru tongue is estimated to range from 50,000 to 70,000 (Saar); in addition, there are also other forms of spoken South Estonian in which also books are published. A comparison could be made with the Saami language and literature. The number of people who speak different forms of Saami is certainly smaller, amounting to 30,000-35,000 (Pohjois-Suomen... 2010: 191), which nevertheless casts no doubt on the existence of Saami literature. Thus, the question is not one of quantitative parameters. What still needs to be explored is the literature's inherent qualities, different ways of defining it, and the issue of how the South Estonian "special question" has arisen in the first place.

\section{The background of South Estonian literature}

Speaking of South Estonian literature presupposes that there are extraliterary conditons that support such a mode of speaking. There are several, with the historical administrative division, linguistic situation and special features of regional cultures being the most important ones. All these aspects taken together could provide a preliminary basis for the description of a collective identity.

Around the year 1200, at the start of the spreading of Christianity on the present Estonian territory, a major part of South Estonia belonged to the counties of Sakala and Ugandi (Eesti ajalugu II 2012: 39). As a result of the conquerors' occupation a territory new for Estonia was formed that more or less coincided with the territories of present-day Estonia and Latvia and was called Livonia in the Middle Ages; later, "Old Livonia" has come to denote the region to underscore the difference from the modern administrative division (Eesti ajalugu II 2012: 11) 39). The formation of the latter was one of the most significant political and administrative changes that influenced the separation of South Estonia. As a result of the establishment of Swedish rule, the provinces of Estonia and Livonia were formed in the $17^{\text {th }}$ century (Eesti ajalugu III 2013: 229). Livonia came to denote a region comprising contemporary South Estonia and North Latvia. In general outlines, the division was retained even after Swedish rule was replaced by that of Russians in the area. The provinces disappeared only after the gaining of Estonian national independence in 1918. Then also other important territorial changes occurred, the most significant of them from the South Estonian perspective being the unification of the Setumaa territories, that had been under Russian jurisdiction, with Estonia (Eesti ajalugu VI 2005: 62). The Setu dialect is a linguistic variety of South Estonian, which gave a sound explanation to uniting Setumaa with Estonia, although the cultural background of the Setus is in many ways different from that of the other South 
VELSKER

Estonians. Later, a part of the Setu territories has been reclaimed by Russia and this has been causing heated debates concerning the border that are also reflected in literature. For instance, the recent anthology of Setu-language poetry (Seto luulo ... 2014) makes it possible for us to define poetry on the topic of the political border as a particular type of modern poetic composition.

Language history looks at South Estonian as an ancient Baltic-Finnish tribal language (Pajusalu et al. 2009: 63). The language would have been the basis for later South Estonian dialects, while the dialectal boundaries themselves emerged in the $17^{\text {th }}$ and $18^{\text {th }}$ centuries (Pajusalu et al. 2009: 70). This was a time when the new boundaries of Livonia were established and written works started to evolve side by side in North as well as in South Estonian, which led to the emergence of two parallel literary languages. The South Estonian dialectal area is usually divided into Mulgi, Tartu and Võru dialects (Pajusalu et al. 2009: 165), while the Setu dialect has mostly been considered a subdivision of the Võru dialect, although it is also possible to foreground it as the fourth independent dialect. The boundaries of the dialectal regions, however, do not entirely coincide with the administrative borders that were valid from the $17^{\text {th }}$ to the $20^{\text {th }}$ centuries, yet it is obvious that the administrative and linguistic divisions have had a mutual influence upon each other.

The main basis for the South Estonian literary language was the Tartu dialect; thus, the Tartu language has often been mentioned. The Northern part of the province of Livonia covered a larger territory in Estonia than that covered by South Estonian dialects; the Tartu literary language in its turn covered an area that was smaller than the spread of South Estonian dialects. The main reason for the vanishing of the Tartu literary language was the relatively small number of its users in comparison with North Estonian speakers. In the first half of the $19^{\text {th }}$ century books published in the Tartu language would make up $19 \%$ of all books in Estonian (Ross 2005: 133), after that the number diminished noticeably. South Estonian dialects would continue to appear in literature, but the continuity of the tradition of a literary language was cut short.

A new stage in the use and interpretation of the dialects spoken in South Estonia arrived in the late 1980s when a South Estonian identity was brought into being in a new manner. In particular, the Vorru cultural movement gained momentum, one of its main issues being an agreement upon the rules of the Võru literary language. Starting from the 1990s it became usual to speak of the Võru language or (Võru-Setu language) and to avoid the term “dialect". In case of the Võru language there are reasons for speaking of it as a subdivision of Estonian, but in describing the relations of scope and hierarchy the term "minority language" is often used, stressing the relative independence of the Vorru language and making it equal to other minority languages spoken in Estonia. 
South Estonian language and its two literary varieties (Tartu and Võru) have given us most reason to speak of South Estonian literature. At the same time the fact that also other languages have been used in South Estonia cannot be disregarded. In the early Middle Ages areas inhabited by the speakers of the Livonian language reached today's South-Western Estonia; later, they would withdraw further south, and Livonian literature would arise on the territory of the present-day Latvia. After the invasion by the crusading orders in the $13^{\text {th }}$ century new languages were introduced in the occupied territories, first and foremost Latin and Low German. The latter was also the lingua franca of the Hanseatic League, but was replaced by German in the $16^{\text {th }}$ century (Eesti ajalugu II 2012: 303). In the same way, the use of Latin in cultural communication was reduced and the use of Russian grew. In broad outlines, the regional cultures spread in South Estonia have historically been in a situation analogous to that of the cultures elsewhere in Estonia. The historical situation that reigned for centuries inevitably linked the high and the popular culture not only to status but also to language. Latin, Low German and German were the languages of the upper classes and have been carrying regional literary traditions as well; starting from the $19^{\text {th }}$ century also the local literature in Russian started to gain strength.

Would this give us reason to speak of South Estonian literature in German or Russian? Cultural history does not give a clear ground for that as for the users of those languages the division between South Estonia and North Latvia would have been of secondary importance, and what was significant was the identity that was formed in the province of Livonia or in the Baltic provinces more generally. The question may still require returning to in the future, as also interlingual cultural communication has to be taken into account, as well as the fact that later literature in South Estonian occasionally may value earlier authors writing in other languages as its predecessors. Thus the play Tandsja pühälik (The Holy Dancer) by Kauksi Ülle and Sven Kivisildnik concentrates on the life history of Juliane von Krüdener, the Baltic German author and religious figure; starting from the premiere of the play in 1996, Krüdener can in some sense be spoken of as an author who has been incorporated into the South Estonian tradition, despite her having been writing mostly in French and German.

The literatures in North and South Estonian languages necessarily emerged against the background of literary predecessors, but were also rooted in folk culture. Scholars of the latter have differentiated between three major regions in Estonia: North Estonia, South Estonia and West Estonia, while it is the areas of Mulgimaa and Setumaa that stand out more clearly in South Estonia (Eesti rahvakultuur 2008: 452). What seems to be most important here is the particular features of the Setu culture: historically, Setumaa has fared differently from the rest of Estonia, the governing rulers (and their language) have been different, 
VELSKER

and there is a religious difference that is of principal importance - the Setu area has been dominated by the Orthodox faith that has not achieved a similar significance elsewhere.

A separate topic of interest that will deserve closer attention in the future is the influence of the ideology of the relatedness of Fenno-Ugric languages on South Estonian identity. It seems that the rise of the Voru movement can be connected with a new type of treatment of the Fenno-Ugric cultures. One of the backgrounds for the emergence of this approach is the "Fenno-Ugrification" and spread of the Ethnofuturist ideology starting from the 1990s. Young Estonian authors started to promote Ethnofuturism as a radical literary phenomenon and it quickly gained ground. The concept of Ethnofuturism has spread in the cultural circles of several Fenno-Ugric nations, particularly due to the committed activities of the Võru-language author Kauksi Ülle, the results of which can be noticed in several places. For example, when Ilmari Leppihalme and Tuula Virsiheimo comment on the poetry of Kari Sallamaa in Finland in 2010, they speak of him as an Ethnofuturist, at this stage not even indicating the source of the concept. The one-time futurist component has become diluted in this treatment; the readers are given the explanation that Ethno-futurism is an artistic formulation of survival skills that aims at the preservation of small nations and languages and the development of their cultures (Pohjois-Suomen... 2010: 88). Such a conception is also suited for the position of a South Estonian culturalideological basis.

In recent times, South Estonian identity has been studied from several aspects. From a literary perspective the works that concentrate on the relationships of language and identity are the most important ones. Two questionnaires with a sociolinguistic focus were carried out in South Estonia on the initiative of the Vorru Institute in 1997 and 1998. The first one was conducted in the part of Setumaa belonging to Estonia, the other in Võrumaa, Valgamaa and Põlvamaa. Both the Setu and the Vorru people considered the use of the local language to be important, but it had a somewhat different meaning for both groups - while there were more people who would consider the local language the most important defining characteristic of a person of Võru origin, folk culture emerged as the decisive characteristic of the Setu identity (Eichenbaum, Pajusalu 2001: 486). According to the data of the questionnaire, another important difference appears in self-identification: $99 \%$ of the Võru people simultaneously considered themselves to be Estonians, while a double-layered identity appeared to be considerably less common in Setumaa where as much as 38\% of the respondents defined themselves as only Setu and not Estonian (Eichenbaum, Pajusalu 2001: 487-488). 
From the point of view of literature one of the most telling results emerging from the questionnaire was the fact that no answer highlighted the possibility of calling the local language South Estonian (Eichenbaum, Pajusalu 2001: 484): either narrower and more particular names are used, or else the language is defined more broadly as Estonian. In the discussions of literature, this special feature refers back to the "terminological inconsistency" mentioned at the beginning of the article.

The problem indeed exists, but there are still at least three points that could be raised in support of the term "South Estonian". First, the scholarly dimensions of discussing literature need not necessarily correspond directly to descriptions of identity; the situation is partly similar to the one in linguistics in which the lack of a "general" South Estonian linguistic identity is acknowledged and even emphasized, while the South Estonian language is still being talked about (e.g, Iva 2008: 6). Second, if we are to observe the possibilities of creating narrower definitions of South Estonian literature that would be more supportive of identity (e.g. Võru literature), these should still be discussed in a broader South Estonian context. Third, the studies referred to describe the (more or less) contemporary situation, while there is reason to think that identities are dynamic, they change across time, and things may have been different in the past.

Although literature is very strongly connected with the choice of the language and linguistic identity, it could still be deliberated whether South Estonian literature could possibly be defined as a translinguistic phenomenon, mostly on the basis of place-bound identity. This possibility does not emerge in the previous treatments, the reason probably still being that the representatives of different social layers and speakers of different languages have defined their "own space" in different ways for themselves. More clear-cut cultural communities have arisen within the boundaries of administrative divisions; in case of the evolving of literary identities towns have had a more important role. In case of South Estonia, this means in particular the foregrounding of Tartu as a literary and cultural centre. The cultural and literary significance of Tartu has been observed now and again, often through the opposition of the two larger cities of Estonia: Tartu contrasted with the capital Tallinn. Thus it has been discovered that Tartu can be seen a "crossing point for several vectors a marker for the linguistic border between southern and northern dialects of the Estonian language, and a porous boundary between rural and urban cultures" (Kirss 2006: 33).

As an intermediate conclusion it can thus be claimed that extraliterary conditions and in particular the differentiation of South Estonian and North Estonian languages give reason to talk of separate literary traditions as well. The differences listed are not unambiguous, though; traditions have been named in 
VELSKER

various ways and double identities are fairly widespread. This lack of unambiguity, however, should not deter us from speaking of South Estonian literature.

\section{The boundaries of South Estonian literature and of conceptualisation of literature}

As admitted at the beginning of the article, the discussions of South Estonian literature have mostly been produced in the past few decades. Why has there been no spread of such modes of description earlier, as the preconditions for it must have been present even then? The reason mostly lies in the traditions of describing literature. The history of describing literature is transforming side by side with the history of literary texts; for this reason it now seems convenient to observe these phenomena together: to describe the boundaries and reception of South Estonian literature and at the same time highlight problems that are revealed by such descriptions. Of course, I have to admit to adhering to certain points of departure, considering the discussion above. First, my starting point has been the conviction that South Estonian literature exists despite all the possible question marks. Second - the most productive approach seems to be taking the use of the South Estonian language in literary texts as its primary defining characteristic. How rigidly this definition should be applied has depended on the researcher. One of the best known Vorru authors and critics Kauksi Ülle has made concessions to some authors who have opted for not using the regional language in their works (Kauksi Ülle 2000: 272-273). Although her concessions have been criticised as well (see Valper 2006: 106), a flexible approach in which single characteristics make up a part of a larger set seems to be justified. In this set, language is of a particular importance, but in some cases it has become compensated by other characteristics (the topics and attitudes emerging in the works; the origin of the author; the territorial boundaries of cultural communication etc.).

A flexible language-centred approach can lead to various accounts, yet what seems to be more or less inevitable is the fact that three major periods can be detected in the history of South Estonian literature, variations appear in describing shorter subperiods and choosing the emphases. The three major periods are not equal in duration and using concrete dates to mark their boundaries is arbitrary, yet they are still justified. The suggested dates for the periods are the following: I - 1622-1916; II - 1917-1986; III from 1987 to the present day.

The first and the longest period designates the rise and fall of the initial literary language in print; the rise and the fall can also be viewed as subperiods, with the boundary separating them remaining in the $17^{\text {th }}$ century. The language 
used is generally the one that has been called the Tartu language above. It is true that the first book that contains South Estonian, a Catholic handbook of religious rites (Agenda Parva, 1622), appeared at a time when the rules of writing in this language had not become established as yet; more explicit agreements concerning the rules were reached some decades later. It is particularly in the $17^{\text {th }}$ century that the South Estonian literary language was capable of competing with North Estonian when it came to publishing religious literature; after the Catholic Counter-Reformation these were predominantly Lutheran publications. The catechism and the gospels in the Tartu language appeared in 1632, the first collection of hymns was published in 1685 and a translation of the New Testament in 1686. Although a translation of the Old Testament had been started already, the entire Bible was never published in South Estonian. According to the commonly spread opinion, the publication of the full Bible in North Estonian in 1739 was the decisive factor in the competition between the languages. It certainly was one of the factors among others, but, as shown by research (Ross 2005), important decisions in favour of North Estonian were nevertheless made earlier than that. As was to be expected, both Estonian as well South Estonian written poetry and fiction were born out of religious literature: hymns gave rise to the development of verse culture, and the tale JerusalemmiLina hirmsast Ärrähäetämissest (The Most Terrible Destruction of the City of Jerusalem) that appeared in 1691 as an appendix to a church handbook may roughly be considered the first prose text in South Estonian that was quickly translated into North Estonian.

Naturally, also folklore existed at the time and in some rare cases it could be recorded in print, but in a more typical case folklore and the written text stayed separate. In the $18^{\text {th }}$ century the first verse examples arose of how literary traditions can exist also independently of the institution of the church - in the $17^{\text {th }}$ century occasional poetry had appeared in the Baltic provinces as a European import that inspired writers to attempt writing in local languages. German poetics usually set the pattern on the territory of Estonia and Livonia, contacts with the aesthetics of older folklore were more sporadic. However, occasional poetry in the local language was more widespread in North Estonia, while there are but a couple of examples recorded in the Tartu language. From among those the latest, the least typical and the best known is "Oh, ma vaene Tardo liin!" "Oh me, poor town of Tartu”, 1708), a lengthy verse lament by Käsu Hans that speaks of the siege and destruction of the town of Tartu by Russian forces during the Great Northern War from a Swedish supporter's point of view. After the war, publication of religious literature in South Estonian was continued into the $18^{\text {th }}$ century, but no new rise would be forthcoming. Among the new tendencies, the $18^{\text {th }}$ century saw the beginning of the religious movement of the Moravian 
VELSKER

Brethren which was particularly influential in Urvaste in Võrumaa where the pastor Johann Christian Quandt became the leader of the movement, increasingly more seriously opposing the Lutheran church that he originally had been a representative of. Quandt and his collaborators organised translational activities and publishing works in the Tartu language. The Moravian Brethren have had a dual impact on cultural history: for the first time, "the people's voice" gained broader cultural resonance, yet at the same time they opposed the peasants' ancient beliefs and culture even more severely than the Lutheran church.

It was only to be expected that questions of the literary language should be topical in the $17^{\text {th }}$ and $18^{\text {th }}$ centuries, but the question of a South Estonian literature in today's sense was not posed at the time - this could not be expected, insofar as neither the self-value of a literary tradition nor ethnic identity had become properly manifested as yet.

In the $19^{\text {th }}$ century the attitudes changed, yet they did not bring along a situation more favourable to South Estonian literature - rather, the circumstances became less favourable. At a time when the amount of printed material in North Estonian was on a steady rise, the number of publications in the Tartu language was diminishing. The last known printed work in the old Tartu-language tradition appeared in 1915 (Paatsi, Ojala 2013: 19). The small range of the linguistic region mentioned above meant economic unprofitability from the point of view of the publishers - it was more expedient to aim for larger print numbers and to do this by overcoming the differences in the North and South Estonian languages. This endeavour found a counterpart in the movement of the Estonian national awakening that strove for the unification of Estonians. The idea that the parallel use of two smaller languages would undermine the movement became standard and was transferred into the conceptualisation of literature. The author of the first Estonian literary history in the Estonian language describes the situation sofar, but takes an explicitly disapproving stand when it comes to the differentiation between literatures in North and South Estonian (Hermann 1898: 61).

Although a tradition disappears, something new emerges in the $19^{\text {th }}$ century and at the beginning of the $20^{\text {th }}$ century as well, which provides an opportunity for a continuation in literary history in the future. The new element becomes apparent most directly in the secular poetry in South Estonian. At the end of the $18^{\text {th }}$ century and in the early $19^{\text {th }}$ century Gustav Adolph Oldekop who was active in Võrumaa as a pastor and a journalist, gained attention with his popular song texts. In the second half of the $19^{\text {th }}$ century Estonian national movement emerges and although unification of the language is being promoted, there still are a few authors who use the language spoken at home in their poetry about their home region. The most remarkable writers among them can be found 
among those coming from the area where the Mulgi dialect was spoken - e.g. Friedrich Kuhlbars, Andres Rennit etc. Some isolated, but impressive, examples can be detected elsewhere - e.g. Gustav Suits in the early $20^{\text {th }}$ century whose texts in the Tartu language have probably been more influential than might be presumed judging by their small number. Examples of the use of the local language in drama and fiction, in which a part of the dialogue is sometimes rendered in South Estonian, are less frequent. This, together with other markers of a regional nature, occurs in the work of August Kitzberg from Mulgimaa or Jaan Lattik from Võrumaa.

The revolutionary year of 1917 can serve as the threshold of the second major period as the publishing of religious literature in Tartu language had recently stopped, while a new wave of poetry in South Estonian was emerging. Artur Adson, a Vorru-language poet, and Hendrik Adamson, a Mulgi-language poet, published their debut collections in 1917 and 1919, respectively. They would prove to be the most direct formative influences on the tradition of South Estonian poetry that is the starting point for later authors, e.g. Raimond Kolk, a Võru poet who was active in Sweden after World War Two. The traditional forms used by the poets (Adson in particular) and their frequent addressing of the realia of their home region and memories of their childhood helps to carve out a niche poetry in South Estonian; fictional texts in South Estonian continue to be less frequent and the niche is less recognisably marked. Later reception has discovered an important predecessor to South Estonian fiction in the work of Juhan Jaik, particularly considering his two-volume collection Võrumaa jutud (Tales from Võrumaa, 1924-1933). In some tales Jaik made use of the Võru language, but what is more important in his case is the folklore material deriving from Vorrumaa and the emphasis laid on the local identity.

Before the 1980s poetry in South Estonian was in the best case interpreted as dialectal literature that would enrich Estonian literature, but only on the condition that it was subordinated to the rules of the "major" Estonian literature - it is not possible to recognize a separate South Estonian tradition in the light of the prevailing ideology. Questions related to South Estonia give rise to tellingly ambiguous position-taking among the critics at the time. Here, the opinions of Friedebert Tuglas who had a strong influence on $20^{\text {th }}$-century literary criticism in Estonia stand out in particular. He supports publishing poetry in South Estonian and speculates on the specific South Estonian features, suggesting that (differently from North Estonia) these might be conducive to the rise of authors writing in the lyric mode (Tuglas 1914: 11). However, he still supports the traditional critical stance towards the development of two literary languages in earlier history (Tuglas 1936: 24) - thus, South Estonian works do represent certain specific values, yet these values should not endanger the unity 
of Estonian literary history. Interesting deviations from this ideology can be detected in the 1920s when the inhabitants of Setumaa were being integrated into Estonian society and a pedagogic programme together with accompanying literature was launched with this aim in mind. Naturally, the programme was in the interests of a unified nation state, yet as an alternative there was the idea that integration is possible only when cultural and linguistic particularities are respected. For instance, Paulopriit Voolaine compiled two Setu readers that stressed that a Setu name should be "an honour and a pride" for its bearer (Seto lugõmik 1923: 5). The selection of texts in these readers among other things shows an attempt to construct a Setu literary tradition.

However, such ambitions waned and the position appealing towards a linguistic and literary unity dominated Estonian literary scholarship up to the 1980s, despite the changes in political rule and statehood as well as in the general outlook on literature and literary criticism. It is true that alternative points of departure appear in the 1960s and a new recognizable wave of South Estonian poetry can be observed with Ain Kaalep as one of the designers of its ideologic programme whose ideas would later be employed by the Võru movement. Kaalep collected his poems in the Vorru language into a separate collection published only at the end of the century - Haukamaa laulu' (Songs of Haukamaa, 1999). The new wave gained momentum, supported by the fact that in addition to the authors who would identify themselves strictly locally, some renowned Estonian authors started publishing poetry in South Estonian - in addition to Kaalep also Jaan Kaplinski and Mats Traat. As before World War Two, also in the 1970s South Estonian fiction remained in the shadow of poetry, but it did exist, particularly in the works of Mats Traat who originally comes from Tartumaa.

In the history of South Estonian literature and literary interpretation 1987 symbolically suits the position of the starting point of the latest, the third period for it is in this year that two works in the Vorru language appeared that would become significant: Kauksi Ülle's first collection of poetry Kesk umma mäke (On Top of Hill of One's Own) and the first full-length play in Vorru language, Põud ja vihm Põlva kihelkonnan nelätõistkümnendämä aasta suvõl (Drought and Rain in Põlva Parish in the Summer of 1914). What is characteristic of the new period is the creative continuity in poetry, accompanied by a rise of fiction and drama that hitherto had been occupying an uncertain position in comparison with poetry. Kauksi Ülle, who initially embodied a continuity in poetry traditions also widened her sphere of activity; she became the author of Paat (The Boat), the first novel written consistently in the Vorru language, and has also been writing plays. The play Taarka (2004), based on the life history of the Setu folk singer Taarka and serving as the basis for a feature film made in 2008, became particularly popular; the film could be considered the first film in the 
Setu language in history. The other key figure in South Estonian drama was Madis Kõiv who wrote plays in the language; also a volume in the series of his memoirs is in the Vorru language. What is important is that the literary wave that started in the late 1980s did not fade away, but increasingly more authors started publishing their works in South Estonian (e.g Merca, Contra, Jan Rahman, Aapo Ilves, Andreas Kalkun, Evar Saar, etc.). Also some authors of the older generation reach a manifestation of a South Estonian identity at a more advanced age, e.g. Mats Traat in his grand novel sequence Minge üles mägedele (Go Up the Hills, 1979-2010).

The rise of South Estonian and particularly the Vorru cultural movement brought along new views on South Estonian literature that was being defined in a way that had no precedents in history. In a way, the situation was similar to the developments in the rest of the world - the increased attention to minorities and their cultures apparent in the West starting from the 1960s also occurred in Estonia, yet with some belatedness and in a specific way. David Perkins has described how the construction of the literary traditions of oppressed and $\mathrm{mi}$ nority groups unfolds, while pointing at the resulting literary histories that have mostly been written for the same reasons that were behind the $19^{\text {th }}$-century local and regional literary histories (Perkins 1992: 9-10). This can certainly be observed in the conceptualisation of Vorru literature as well; one of the most important sketches of South Estonian literature that has been influential regarding later attitudes comes from Kauksi Ülle (Kauksi Ülle 2000) and this work really shows the wish "to construct a people" that accompanies several earlier literary histories. As a characteristic feature, a terminological slip occurs in the text - the title speaks of Vorru literature, while the proposed literary history is entitled "Lõunaeesti kirändüse aolugu säitsmen jaon" ("History of South Estonian literature in seven parts"). I have been discussing the possiblities of writing a South Estonian literary history in my dissertation (Velsker 2014), not proposing a "finalised" history, but rather weighing different options that could be resorted to by someone engaged in writing one.

Thus, the answer to the question whether South Estonian literature is seen as an independent tradition or a dialectal part of the Estonian tradition depends on the critic's angle of approach and ideological background. The same background, however, is also shaping literary production and thus the issue of the separate existence of South Estonian literature cannot be dismissed with the claim that it is merely a construct created by literary scholars and critics. The impossibility of this can also be noticed when an attempt is made to employ the classic $20^{\text {th }}$-century theory of literary dialect in connection with South Estonian literature. This will be feasible to a degree, yet also reveal problems: for instance, Sumner Ives, using examples from English, points out how dialectal writers may 
VELSKER

use dialect to achieve humorous effects, or how it is used for realist effect by "serious writers" (Ives 1971: 146). When observing examples from the classic tradition of Estonian prose, these could indeed be the reasons why dialect is resorted to. If, however, poetry and contemporary texts of fiction and drama are also taken into account, such explanations will obviously fall short - an important aim of more recent texts in local languages also seems to be supporting the local identity. Local identity may mean double identity, yet this does not mean that the one is necessarily subordinated to the other, with the local element being subordinated to the "major" Estonian feeling of unity; in literature, this can be seen more frequently than in many other fields.

It became clear in the article that in certain cases the definition of also relatively small literary traditions may be justified, even though the identity relations behind these traditions may be complicated and create variations in the common denominations covering identity and literature. The history of South Estonian literature, whose most salient characteristic features we have been observing, can be used to demonstrate how conceptualising stances keep changing throughout history together with literature itself. In the discussions typical of the $20^{\text {th }}$ century, the question of South Estonian literature is mostly concerned with the enriching contribution of dialects to Estonian literature; the point of view from the threshold of the $21^{\text {st }}$ century appears to reveal something more - a separate existence of South Estonian literature. Although in the history of literary interpretation South Estonian literature is a relatively new phenomenon, it can still boast of a centuries-long history.

\author{
Mart Velsker \\ mart.velsker@ut.ee \\ Tartu Ülikool \\ Kultuuriteaduste ja kunstide instituut \\ Ülikooli 16 \\ 51003 Tartu \\ EESTI
}

\title{
References
}

Eesti ajalugu II. Eesti keskaeg 2012. Anti Selart, ed.. Tartu: Tartu Ülikooli ajaloo ja arheoloogia instituut.

Eesti ajalugu III. Vene-Liivimaa sõjast Põhjasõjani 2013. Ed. by E. Küng, M. Seppel. Tartu: Tartu Ülikooli ajaloo ja arheoloogia instituut.

Eesti ajalugu VI. Vabadussõjast taasiseseisvumiseni 2005. Ed. by S. Vahtre, A. Pajur,

T. Tannberg. Tartu: Ilmamaa. 
South Estonian Literature: A New Phenomenon with a Centuries-long History

Eesti rahvakultuur 2008. Ed. by A. Viires, E. Vunder. Tallinn: Eesti Entsüklopeediakirjastus.

Eichenbaum, K., Pajusalu, K. 2001. Setode ja võrokeste keelehoiakutest ja identiteedist. - Keel ja Kirjandus, 7, 483-489.

Glesener, J. E. 2012. On Small Literatures and Their Location in World Literature. A Case Study on Luxembourgish Literature. - Interlitteraria, 17, 75-92.

Hermann, K. A. 1898. Eesti kirjanduse ajalugu esimesest algusest meie ajani. Tartu: K. A. Hermann.

Iva, S. 2008. Lõunaeesti ja võru keel: mõisted ja keelepuu. - Oma Keel, 2, 5-12.

Ives, S. 1971. A Theory of Literary Dialect. - J. V. Williamson, V. M. Burke, ed. A Various Language. Perspectives on American Dialects. New York: Holt, Rinehart and Winston, 145-177.

Kauksi Ülle 2000. Võro kirändüs - miä tuu um? - Kauksi Ülle, N. Reimann, eds., Võro kirändüse luumine. Võro Instituudi toimõtiseq 7. Võru: Võro Instituut́, 264-273.

Kirss, T. A. 2006. The Tartu/Tallinn Dialectic in Estonian Letters and Culture. M. Cornis-Pope, J. Neubauer, eds., History of the Literary Cultures of East-Central Europe. Junctures and Disjunctures in the $19^{\text {th }}$ and $20^{\text {th }}$ centuries. Vol. II. A Comparative History of Literatures in European Languages 20. Amsterdam, Philadelphia: Benjamins, 28-37.

Paatsi, V., Ojala, U. 2013. Tartukeelne kirjasõna ja selle hääbumine 19. sajandi algusest Eesti Vabariigi loomiseni. - M. Velsker, K. Tüür, eds., Kohalik kirjandus: lõunaeesti vaateid. Kotusõkirändüs: lõunõeesti kaehuisi. Konverents Tartu Ülikoolis. Konvõrents Tarto Ülikoolin 15.-16.11.2013. Tartu: Tartu Ülikool, 19-20.

Pajusalu et al. 2009 = Pajusalu, K., Hennoste, T., Niit, E., Päll, P. Viikberg, J. 2009. Eesti murded ja kohanimed. Tallinn: Eesti Keele Sihtasutus.

Perkins, D. 1992. Is Literary History Possible? Baltimore and London: The Johns Hopkins University Press.

Pohjois-Suomen ... $2010=$ Pohjois-Suomen kirjallisuushistoria. Suomalaisen Kirjallisuuden Seuran toimituksia 1261. Ed. by S. Carlsson, L. Huhtala, S. Karkulehto, I. Leppihalme, J. Märsynaho. Helsinki: Suomaisen Kirjallisuuden Seura.

Rahvaarv ... = Rahvaarv, pindala ja asustustihedus maakonna järgi, 31. detsember 2011. - Eesti Statistika - http://www.stat.ee/67696 (07.02.2015).

Ross, K. 2005. Miks ja millal kaotati esimene lõunaeesti kirjakeel? - Vikerkaar, 7-8, 130-139.

Saar, E. Võru keel. - http://www.wi.ee/index.php/voru-keel (07.02.15).

Seto lugõmik. I osa 1923. Akadeemilise Emakeele Seltsi toimetused VI. Tartu: Akadeemiline Emakeele Selts.

Seto luulõ ... 2014 = Seto luulo antoloogia. Seto kirävara 9. Ed. by Kauksi Ülle. Värska: Seto Instituut.

Tuglas, F. 1914. Juhan Liiv. Monografia. Eesti kirjanikkude seltsi „Noor-Eesti” toimetus 25. Tartu: Noor-Eesti.

Tuglas, F. 1936. Lühike eesti kirjanduslugu. Tartu: Eesti Kirjanduse Selts. 
VELSKER

Valper, V. 2006. Mitmõkeeline võro kirändüs. - M. Mets, ed., Tartu Ülikooli LõunaEesti keele-ja kultuuriuuringute keskuse aastaraamat V. 2005. Tartu: Tartu Ülikooli Lõuna-Eesti keele- ja kultuuriuuringute keskus, 106-117.

Velsker, M. 2014. Lõunaeesti kirjandusloo kirjutamise võimalusi. Dissertationes litterarum et contemplationis comparativae Universitatis Tartuensis, 12. Tartu: Tartu Ülikooli Kirjastus. 